\title{
NEGRO SOBRE BLANCO: ECOS INFANTILES DE UNA GUERRA
}

A propósito de Verónica Sierra Blas, Palabras huérfanas: los niños y la Guerra Civil, Madrid, Taurus, 2009, 434 págs.

"No siempre resulta fácil mantenerse al margen, incapaz de hacer nada, salvo reflejar los sufrimientos que te rodean".

RoBert CAPA

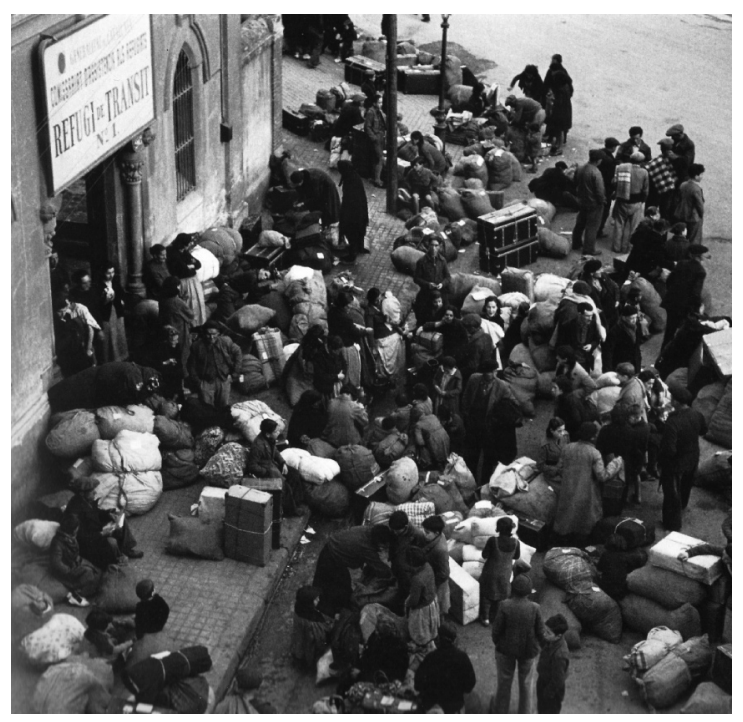

Robert CAPa, Un centro de acogida de refugiados, Barcelona, enero 1939. MNCARS, AD 872.

Desvelado hace años (o al menos eso parecía, después de la reciente investigación de José Manuel Susperregui que trastoca el asunto de la localización y la fecha) el prolongado enigma en torno al miliciano de la FAI, Federico Borrell, alcanzado 
mortalmente en Cerro Muriano (Córdoba) la tarde del cinco de septiembre de 1936 (publicada originalmente en $V u, 23$ de septiembre) se podría plantear a continuación un interrogante similar acerca de la identidad que se esconde tras otra célebre foto del mismo Capa. Fue tomada en el Refugi de Transit número 1, dependiente del Comisariat d'Assistencia als Refugiats de la Generalitat, casi tres años después, en una Barcelona sitiada por las tropas de Franco, a punto de verificar su inexorable rendición. De la muchacha que sirve a Verónica Sierra Blas como ilustración de cubierta para sintetizar con gran acierto sus Palabras Huérfanas, recupero únicamente el comentario que al propio Capa le suscitó su rostro, a modo de pie de foto, reproducido aquí como introducción a estas líneas.

De las aproximadamente 937 imágenes de la Guerra Civil que Capa tomó durante su paso por España, ésta no fue la única fotografía que muestra a niños haciendo, sufriendo o contemplando la Guerra. Sin embargo, es evidente que de todas ellas, la seleccionada por la autora conmueve de manera singular. Junto a los niños, otros objetos asociados serán sinónimo de abandono, de movilización apresurada y de huida urgente: maletas, fardos, sacas, hatillos de última hora, bolsas en las que rápidamente se introdujeron enseres, utensilios de primera necesidad, ropas, tal vez cartas. Ambos elementos quedan tan perfectamente recogidos en esta instantánea que se convierten en un símbolo de cualquier conflicto, constantes atemporales del eterno sufrimiento de las llamadas "víctimas colaterales" de la Guerra. Es interesante observar que un somero análisis de las fotografías tomadas aquel día nos ofrece algún detalle complementario sobre la niña de la imagen con su abrigo inconfundible, mezclada entre el gentío, hombres, mujeres y niños que rodeados de bultos y enseres personales aguardaban no se sabe qué. Ahí está, en el centro inferior de la imagen aproximadamente, el perfil apenas perceptible de la niña, antes o después de haber posado para Capa, antes de recostarse sobre el saco de arroces de una fábrica de Reus que una mujer y tres jóvenes (quién sabe si su madre y sus hermanos) prepararon a modo de improvisado colchón para hacer más llevadera una incierta espera que Capa inmortalizó en un disparo de su cámara.

Será la mirada insondable reproducida en la cubierta la que nos conduzca a modo de guía por las reflexiones que suscita esta magnífica contribución a la Historia Social de la Cultura Escrita Contemporánea. Afectos, desafectos, tristezas prematuras, dolores y heridas a destiempo por tempranas fueron certeramente inmortalizadas por el autor de Ligeramente desenfocado y su mítica compañera, Gerda Taro, cuyos detalles de su inexplicable muerte, aplastada por un carro de combate T-26 en la caótica retirada de Brunete también han sido desvelados 
hace poco ${ }^{1}$. ¿Cómo penetrar en esas almas infantiles lastimadas? ¿Cómo ceder el protagonismo a los miles de niños que sufrieron en grado desigual los rigores de la Guerra Civil Española desde prismas y coordenadas dispares? ¿Cómo registrar, setenta años después, estudiar y analizar convincentemente el "sufrimiento que rodeó a tantos niños y no permanecer al margen"?

Verónica Sierra apostó desde mucho antes de iniciar el andamiaje de lo que sería su tesis doctoral por recuperar estas voces olvidadas, certeros representantes menores en edad, mayores en intensidad de los llamados por Antonio Castillo de forma gráfica y esclarecedora "los de abajo". Antes de llegar a estas cuatrocientas cincuenta páginas de cuidada investigación y esmeradísima redacción, la autora ha demostrado sobradamente su madurez como investigadora y reconocida experta en Historia Social de la Cultura Escrita en el seno del Seminario Interdisciplinar de Estudios sobre Cultura Escrita (Universidad de Alcalá de Henares) que dirige el profesor Antonio Castillo y coordina la propia Verónica Sierra. Además, su coordinación en la edición de la revista Cultura Escrita \& Sociedad y de la Red de Archivos e Investigadores de la Escritura Popular la han convertido por méritos propios en una investigadora de absoluta referencia en su ámbito. Sus numerosas contribuciones a congresos internacionales y su formación con los principales expertos (Chartier, Botrell, Petrucci entre otros), consolidan su autoridad. Entre los notables resultados de toda esta actividad, espigados aquí solamente por razones de espacio, figuran sus estudios sobre los manuales epistolares, sobre la escritura y la lectura en centros de internamiento o las prácticas escriturarias de las madrinas de Guerra durante la contienda española².

Como nos dice la autora en el prólogo, este libro trata de niños (unos 30.000), de la guerra, del exilio y de cómo el paso del tiempo ha hecho posible recuperar la memoria de aquella época gracias a los testimonios y recuerdos de quienes vivieron en una España en guerra. Es también un estudio de tipologías documentales que podríamos enmarcar en el conjunto de testimonios escritos de la llamada "memoria caliente", llena de emoción y sentimiento frente a la "memoria fría" de la burocracia administrativa o la prosa notarial. Así, las cartas enviadas por los niños desde el exilio a sus familias, cartas de súplica, diarios, memorias, postales, dibujos muy dispares, libros de escuela, etc., constituyen la muestra representativa, una vez más, de lo que Antonio Castillo denominó

1. El tanquista del T-26 que involuntariamente pasó por encima del cuerpo de Gerda Taro se llamaba Aníbal González (Albacete, 1918) y, por supuesto, no fue consciente del accidente hasta que unas horas después, un compañero suyo, también tanquista, le refirió lo sucedido. El País, 12 de julio de 2009, p. 47.

2. SierRA Blas, Verónica, Aprender a escribir cartas. Los manuales epistolares en la España contemporánea (1927-1945), Gijón, Trea, 2003. 
la necesidad de la escritura, a veces como la del pan diario, el que tanto faltó a aquellos niños durante la Guerra. Con todos ellos se reivindica al mismo tiempo un capítulo esencial centrado en la recuperación de las prácticas y resultados de la escritura de los de abajo, acaso por ser niños, los más anónimos y menos perdurables de todos: desde la retaguardia madrileña hasta los campos de refugiados de Darfur ${ }^{3}$.

Frente a lo efímero de los trazos infantiles, la paciente búsqueda por archivos y bibliotecas de un impresionante listado de instituciones llevada a cabo por Verónica Sierra, nos ofrece ese filón que permanecía poco explotado como son las huellas escritas de la infancia. Si, además, el período abordado es el comprendido entre 1936 y la posguerra, el interés de los resultados se amplía enormemen$\mathrm{te}^{4}$. Habiendo especificado el tema fundamental en torno al cual se desarrolla esta obra, no es menos cierto que los contextos juegan un papel esencial para comprender los mecanismos y los resultados de la escritura mediatizada por la guerra. Así, los estragos de la transformación de la escuela bajo el influjo omnipresente del conflicto marcaron el día a día de la infancia. Recordemos a este respecto cómo cine y literatura han ahondado en este microcosmos, especialmente en el medio rural, con ejemplos tan dramáticos como lo fue La lengua de las mariposas y su escena final, de una crueldad insuperable o la apurada situación de maestros y educadores republicanos, viejos venerables a eliminar desde Las Bicicletas son para el verano hasta Las largas vacaciones del 36. En todo caso, también la escuela fue considerada un refugio emocional seguro, un espacio de convivencia entre niños, reducto de las expresiones infantiles de afecto y aprendizaje bajo las bombas y en cuyo seno la escritura también jugó un papel terapéutico perfectamente resaltado por Verónica Sierra en su apartado sobre la grafoterapia aplicada al contexto estudiado.

Tras la Guerra, el penoso exilio, la angustiosa huida y el desarraigo temporal o, como en el caso de algunos Niños de Rusia, para siempre. De aquellas circunstancias personales se derivaron numerosos testimonios que, como en tantas otras ocasiones en la Historia, constituyeron los finos pero resistentes hilos que unían corazones en la distancia. No puede olvidarse tampoco la gesta organizativa de las Instituciones y órganos de todo tipo que regularon "la infancia evacuada" y llevaron a cabo las ímprobas tareas de protección y traslado seguro de los niños. Departamentos de Asistencia Social, Comités de ayuda a los niños, albergues y asilos como los fotografiados por Robert Capa aquel día de enero de 1939 en una

3. Abou-Kassem, Óscar, «Los dibujos del horror: cientos de menores de Darfur plasman sus pesadillas para una ONG», El País, 4 agosto 2007, p. 8.

4. Alted, Alicia; González, Roger y Millán, María José (eds.), A pesar de todo, dibujan: la Guerra Civil vista por los niños, Madrid, Biblioteca Nacional, 2006. 
Barcelona agonizante, dan buena muestra de la honda preocupación por la suerte de los niños. Sin el concurso de listas, formularios, folletos explicativos y carteles, el objetivo no se hubiese podido alcanzar. Pero a ellas cupo también determinar cómo llevar a cabo las prácticas escriturarias de aquellos niños con sus familias: materiales, textos y periodicidad del contacto epistolar figuraron entre sus otras atribuciones. En esa comunicación por escrito no faltaron estrategias para burlar la censura, extravíos por malas comunicaciones, interceptaciones del correo por el enemigo, etc., determinando las características de la fortuna de lo escrito.

El niño se vio implicado con independencia o no de su voluntad en la Guerra. Escribir al combatiente dentro de un proyecto político de "memoria de la Guerra" en la escuela fue común en ambos contendientes; contexto que, por otra parte, la autora domina a la perfección tras haber estudiado detenidamente la realidad de las prácticas, los resultados y las representaciones de las madrinas de guerra y sus relaciones epistolares con soldados en el frente ${ }^{5}$.

En sentido estrictamente cronológico, no sólo las penosas condiciones de la salida de España sino también de las penalidades del viaje, de la llegada, de las condiciones de vida en casas y recintos de acogida, fueron mil detalles consignados por escrito. El inicio de la Segunda Guerra Mundial supuso una vuelta de tuerca más sobre las doloridas miradas de los niños todavía no repuestos del conflicto español. Las repatriaciones a España llevadas a cabo durante los años 40 y 50 supusieron otra dimensión lastrada por una gran carga emocional subrayando el anhelo de volver a España como un ideal o un imposible, tal y como concluye la autora.

Este libro no olvida un aspecto tan apenas tratado en España desde la óptica que ocupa y preocupa a Verónica Sierra. Me refiero a la grafopsicología infantil. Como indicó el matrimonio Brauner, los dibujos de los niños eran casi siempre certeros reflejos del estado de ánimo, de la situación particular de cada uno de ellos, con temas y motivos recurrentes (bombardeos, colas del pan, muertos, evacuaciones, aviones, etc.). Este apartado constituye un punto de partida muy prometedor para determinar las características del estudio formal de escrituras y dibujos infantiles de otros lugares, tiempos y contextos: sentido y uso del color, soportes de escritura, tipos de tinta y materiales de escritura, prácticas de conservación, etc.

Palabras huérfanas es, además, un libro agradable a las manos. Su limpia y cuidada edición incorpora una profusa selección de imágenes a todo color en sus

5. SierRa Blas, Verónica, «Escribir en campaña: cartas de soldados desde el frente», Cultura Escrita y Sociedad, 4 (2007), pp. 95-116 y, de la misma autora, «Entre armas y letras», Andalucía en la Historia, vol. 6, n. ${ }^{\circ} 23$ (enero-marzo 2009), pp. 64-69. 
páginas centrales y no se han escatimado esfuerzos para acercar el contenido al lector de una forma amena, didáctica e, incluso me atrevería a decir, casi poética. Porque, para concluir, en toda la escritura de Verónica Sierra subyace una singular y personalísima manera que es el estilo de los autores ya consagrados que además tuvieron la fortuna de formarse entre los mejores maestros. En él se conjuga el rigor de la investigación con la pulcritud de la exposición, siempre teñida de una amable mirada sobre el objeto de estudio. El cariño que siente la doctora Sierra por todo lo que estudia se traslada a la pluma y a la hoja, ofreciéndonos un ejercicio de lectura realmente placentero, en fondo y en forma.

Diego Navarro Bonilla

Universidad Carlos III de Madrid 